\title{
Increasing Productivity of Furniture Factory with Lean Manufacturing Techniques (Case Study)
}

\author{
Dilsad Guzel, Alireza Shahbazpour Asiabi*
}

\begin{abstract}
Lean manufacturing techniques are mostly applied in large enterprises and companies that produce more technological products. In this study, productivity has been increased by the application of lean production techniques in SMEs that produces simpler products and has a lower education level of employees. For this, as the first step, Pareto analysis is performed on the sales and production data of the previous year, and the target product family is selected for improvement. In the next step of the study, improvement projects are determined with the Value Stream Mapping (VSM) method, and then productivity increases are achieved by using Kaizen, 5 S, standard work, layout plan, and singlepiece flow techniques. As a result of the applications, a decrease was achieved in the production process times and the number of quality defects, and at the end of one year, a $29 \%$ reduction in total workmanship is observed.
\end{abstract}

Keywords: flow manufacturing; 5S; lean manufacturing; spaghetti diagram; standard work; Value Stream Mapping (VSM)

\section{INTRODUCTION}

In Turkey, like other countries in the world, SMEs have a great role in the growth of the economy. There are different methods used to increase productivity, but the most used and more widespread among them is lean production applications. The application of lean production techniques has not been applied in detail in SMEs due to reasons such as financial and human resources constraints. When we ask the owners and top managers of companies that do not apply lean production techniques, they think that these methods are not suitable for their scale and work. Womack et al. claim the applicability of lean manufacturing practices despite the size of the firm [1]. When we search the publications, there are very few articles that describe lean manufacturing practices in SMEs in detail. Therefore, this study has been prepared for the purpose of generalizing lean production in SMEs and to show that it is not dependent on the scale and the work done. As a result, it answers the question "Do lean manufacturing practices increase productivity in SMEs?" This study consists of 3 main parts: the first part includes the definition of lean manufacturing, the second part includes application methods, and the third part includes application and results.

\section{LITERATURE REVIEW}

\subsection{Lean Production}

To understand what lean production means in a simple and detailed way, it is necessary to know the definitions of lean production and some basic lean concepts in these definitions. Lean manufacturing constantly focuses on eliminating non-value-added activities and maximizing value-added activities by reducing production costs and improving the quality of an organizational process. In general, non-value-added activities add costs to operations without increasing the value of products. Non-value-added activities are defined as waste in lean production. Any activity that the customer is not willing to pay for is determined as non-value-added and wasteful [2]. Non-valueadded activities can be classified into seven wastes: excess production waste, unnecessary waiting, unnecessary transportation, over-processing, excess stock, unnecessary movement, and defects. Cost reduction and increase in efficiency in operations are realized by eliminating the waste in the process. To eliminate these wastes, techniques such as visual control, 5S, VSM and Kaizen are applied from various lean production tools [3].

\subsubsection{Lean Production Principles}

The lean production system aims at low cost, fast delivery, and a high-quality-oriented foundation. To achieve this basis, the lean production system has 5 principles. Lean production principles consist of identifying value, Mapping the value stream, creating flow, establishing pull, Perfection seeking.

\subsubsection{Value}

A lean manufacturing system requires a change in the usual system and supports the distinction of "value" from "waste", providing studies that will affect the transformation of existing resources into products and/or products. Value is the basic concept in the lean production system. If we define the value briefly, it is the whole of all processes that will meet the expectations and requirements of the customer in the product and/or service formation process. The period starting from the customer's request in the formation process of a finished product, from the raw material entry to the product formation and delivery to the customer, consists of 5 steps [4]: Processing Time, Control Time, Handling Time, Waiting Time, and Storage Time. When we look from the perspective of the customer, the questions of why he wants the product, what he needs, what the product qualities are, how much it is priced and when it can be delivered help to find value criteria. Process steps other than these transactions are products that the customer does not want to pay and do not add value to them. It will be possible to manage customer value with the steps in Fig. 1. 


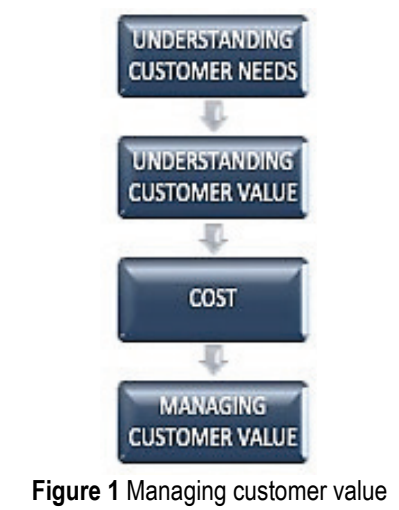

All transactions that do not add value in the process of product and/or service formation, that is, do not contribute to the transformation process of the product and/ or service, are called waste. Taiichi Ohno (1988) defined waste as "a resource-consuming activity that does not create value. In other words, it is an activity that does not add value but creates costs. The list of wastes is: Faulty Production, Overproduction, Excess inventory, Waiting, Overprocessing, Unnecessary Transport, Extreme Movements, Unused Knowledge/ Talent.

\subsubsection{Value Stream}

The value stream is the concrete set of actions required to achieve a particular product and is achieved through the three critical management functions found in every business. The value stream includes all the stages from one producer to another producer and the end user in the process of transforming the raw material into the final product, and it contains an incredible amount of waste. There are three types of activities in production:

- "Value-creating" activities (such as dyeing, assembly, weaving) that transform in the direction desired by the customer

- "Mandatory" jobs that do not create value but are necessary for the customer to do the job (such as molding, adjustment, transportation)

- "Non-value and avoidable" tasks such as waiting, counting, sorting, error, repair

When value streams are examined, it is seen that activities that do not create value, that is, waste, consume most of the time and resources. Elimination of these wastes will bring radical improvements in time and cost. Once value is fully defined, the value stream map for a given product is fully drawn by the lean business, and the wasteful steps are eliminated, it's time for lean thinking to take the next step. What remains is to ensure a continuous flow of valuecreating steps [5].

\subsubsection{Continuous Flow}

It is the uninterrupted flow of processes in the product and/or service formation process that the customer wants to buy. The continuous flow principle in lean manufacturing systems is subject to flow interruptions with usual systems and wrong practices in most organizations. The continuous flow aims to keep everything working and to progress continuously.

\subsubsection{Pull System}

The pull principle, which relates to creating flow, is the process of starting production with customer demand and triggering the previous process from the product to the raw material, instead of the thought of producing and selling in traditional production. With the pull system, fluctuations in demand can be transferred to previous operations, intermediate stocks can be reduced, and simpler production can be achieved by eliminating waste [6].

\subsubsection{Search for Perfection}

It is a process that does not have a waste type, is free from all waste and creates value as defined by the customer. By changing the culture of organizations mostly, it enables them to be directed towards continuous improvement and to develop the organization. One of the most important tools for this is Kaizen. Kaizen makes employees seek improvement opportunities. They also contribute to the pursuit of excellence by supporting the organization's change and development. The pursuit of perfection comes from an effort to achieve more perfect, in a continuous cycle, by thinking that it can be continuously improved. The stages of organizations seeking excellence are accepting the change and starting within their body, showing their stakeholders where they have reached with the change and finally making improvements [7].

\subsection{Lean Manufacturing Techniques 2.2.1 VSM}

The value stream is the set of value-added and nonvalue-added activities needed to produce a product along the main streams essential to each product. The main flows applicable to each product are (1) the production flow from raw materials to the customer, (2) the design flow from concept to installation (product development process) [8]. We usually connect this flow with lean manufacturing, and this is the zone that lean techniques are tried to be implemented. The value stream viewpoint means working on the big picture, not just one activity, and improving all processes, not just parts. If you really look at the whole and follow all the paths from the raw material to the customer, you will need to survive a value stream through many companies and factories. However, mapping a flow of this bigness is too much and difficult to begin with. The first thing that appears in the production flow is the material movement flow in the factory. But there is another flow that tells each process what to do next: the information flow. In lean production, information flow is as important as material flow. You need to map both. The question you have to ask yourself is, "How should we flow information so that one process only produces what the next process wants, when it wants to? 
VSM follows the steps shown in Fig. 2. Note that the "Future State Map" is highlighted because your goal is to design a lean value stream. The current state map is useless without the future state. The future state map is the most important thing. The first step is to draw the current situation by collecting information from the production area. This provides the information you need to design the future state. Also, if you notice, the flows between the current and future situation go both ways. This shows that current and future developments are studies that affect each other. Ideas about the future situation will be formed while drawing the current situation map. Similarly, the future state plot will reveal important previously overlooked information about the current state. The final step is the preparation of an implementation plan and start to application it. A one-page implementation plan defines how we will achieve the future state. Then, when the future state is reached, a new future state map should be drawn [9].

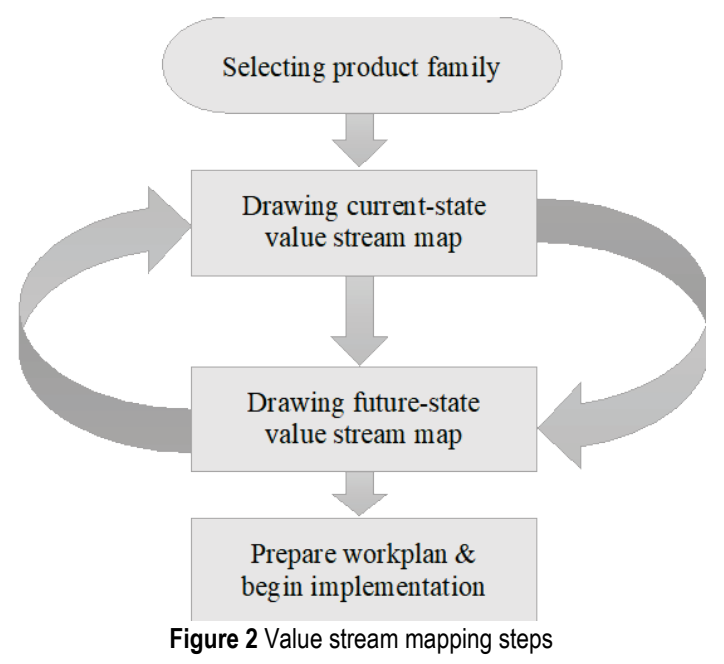

\subsubsection{Spaghetti Diagram}

The spaghetti diagram is an easy yet strong instrument for imagining motion and transportation [10]. Such as diagrams are a well-established tool that seeks more effective layouts [11]. When the transportation routes are sketched, it is often simple to spot potentials to reduce waste in movement. The spaghetti diagram was used to follow and draw worker movements to try to find unnecessary motions that could be eliminated. Furthermore, analyzing the current state may be useful for comparing it with recommended improvements. [12].

\subsubsection{S Method}

The $5 \mathrm{~S}$ is a Japanese technique of organizing the workshop, in a clean, efficient, and safe mode, to gain a productive workspace [13]. The $5 \mathrm{~S}$ is the starting point for companies that want to be recognized in the world class [14]. The 5S technique consists of five steps: a. Sort: Separation of necessary and unnecessary items and elimination of unnecessary items; b. Set in Order: Systematic arrangement of necessary items and so that they can quickly be taken and returned in the original place after use $[15,16,17]$; c. Shine: Cleaning the workplace and equipment regularly. The source of indiscipline, inefficiency, faulty production, and work accidents is dust and dirt $[15,18]$; d. Standardize: Standardization and documentation of methods, use of standard procedures. Standards should be fluent, clear, and easy to understand $[15,18,19]$; e. Sustain: Maintaining the continuity of the established procedures, regularly auditing the working methods, making the $5 \mathrm{~S}$ method a habit and integrating it into the culture. In general, the first three steps are easily applied in the enterprises, but because the fourth and fifth steps are not implemented, it returns to the old situation after a short time. The simple yet powerful $5 \mathrm{~S}$ technique helps identify and eliminate workplace problems [20]. It also helps to have an efficient and high-quality workplace. [21].

\subsubsection{Kaizen}

Kaizen consists of two words, Kai (development) and Zen (continuous), expressing improvement and continuous improvement [22]. Kaizen predicts awareness of problems and gives clues to identify these problems, it is an important management support covering many management practices used in organizations [23].

\subsubsection{Standardized Work}

Berger et al. identified the Standard Work as an important tool for continuous improvement [24]. One of the safest and most effective ways to use resources such as people, machines, and materials efficiently and to make operations sustainable is to apply a standard operating method. Work Standardization can be defined as a set of analysis tools that results in a set of standard operation procedures (SOPs). SOPs show which work steps are followed by the activities performed within the target time. SOPs helps us to eliminate the take-time fluctuation problems. With the increase in demand, we can gradually add workers. If the amount of demand decreases, it can gradually remove workers from the production line $[24,25]$. Standardization is to determine the lower and upper limits of quality in the organization and to ensure that products and services are produced above the determined level [26].

\subsubsection{U-Line Manufacturing System}

In its overview, the entrance and exit of the $\mathrm{U}$ line should be in the same place [27]. With both ends of the line on one side, a narrow $U$ shape is formed. The advantages of $U$ shaped lines are reducing the number of workstations, balancing the line, visibility, and flexibility. Guerriero et al. Stochastic simply described the flexibility of the U-Line layout and suggested that flexibility makes it easier for this line to increase or decrease the number of workers when demand is experienced. As for the installation results of the U-Line, minimum workstation, minimum labor, and a workflow can be determined [28]. 


\subsubsection{Flow Manufacturing}

The principle of flow production is to produce an element at a time at a rate equal to the cycle time. The successful implementation of flow manufacturing requires U-line layout, multi-skilled workers, standardized cycle time, designing operator work as standing and walking way. Miltenburg et al. recommended that the pull through or over long process flow can be balanced by introducing the customized operation in the workstation in order to balance the operation with the workstation cycle time [29, 30]. Mixed flow model is made smooth by designing workstation with quick change and small batch size.

\section{METHODOLOGIES}

There are various methods for current state analysis and increasing productivity in companies. In this study, we follow 5 steps as shown below:

1) Drawing current state VSM for identifying wastes

2) Selection of improvement projects by brainstorming with department workers

3) Using lean manufacturing techniques for applying in improvement projects:

a) $5 \mathrm{~S}$ and Kaizen method used for general settings in workshops

b) Spaghetti diagram used for analyzing and improvement walking distances in a frame workshop layout

c) Standardization Work used for decreasing cycle time in upholstery process

d) Standardization Work used for decreasing paint faults in paint shop

e) U-Line Manufacturing System used for cycle time improvement in upholstery process

f) Flow Manufacturing (One piece flow) used for fabric sewing process.

4) Comparison of productivity criteria before and after application in production processes.

\section{DATA ANALYSIS AND RESULTS}

\subsection{Furniture Manufacturing Current State Value Stream Map}

For drawing the current state map in this factory based on methodology, at first, we select a product family by using Pareto analysis method. In this case, we collect one-year sale data and after that, by drawing Pareto graphics, find the products that were most sold last one year as shown in Fig. 3.

The below steps have been followed for drawing the GST current state value stream map:

1) Collection of customer order information (Monthly customer demand, weekly working days and daily working hours)

2) Determination of information flow from customer order to shipment

3) Determining planning strategy in the current state

4) Identify manufacturing steps and all data related to them (cycle time, changeover time, number of employees, working rate,)
5) Determining work in process parts numbers

6) Calculating of total production time and lead time

7) Drawing the timeline of the current state map.

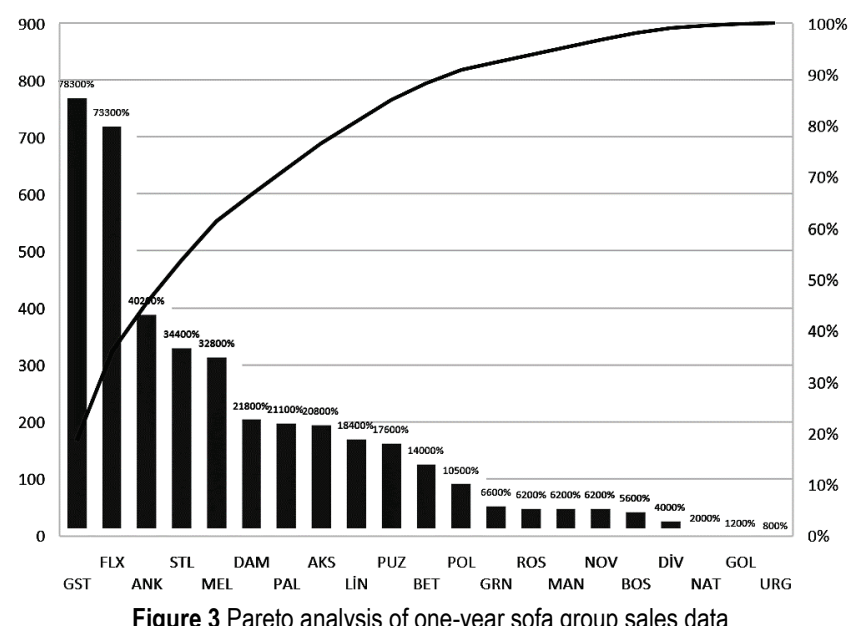

As shown in Fig. 4, the current state value stream was complete by the following steps. At the end of calculations and analysis in the value stream, problems were identified, and improvements projects determinate on a departmental basis.

\subsection{Current State VSM Analysis Results}

According to the results obtained from the analysis of the current state value stream map, the following problems have been identified in the production processes as shown in Tab. 1.

\begin{tabular}{|l|l|}
\multicolumn{1}{|c|}{$\begin{array}{c}\text { Production } \\
\text { Process }\end{array}$} & \multicolumn{1}{c|}{ Problems 1 Process Based problems } \\
\hline $\begin{array}{l}\text { Frame } \\
\text { manufacturing }\end{array}$ & $\begin{array}{l}\text { Unnecessary transportation, Unnecessary movements, } \\
\text { Unorganized workplace }\end{array}$ \\
\hline Painting & $\begin{array}{l}\text { Painting mistakes, Faulty products, Unorganized } \\
\text { workplace }\end{array}$ \\
\hline Fabric Sewing & $\begin{array}{l}\text { Waiting, Unbalanced operations, Unorganized } \\
\text { workplace }\end{array}$ \\
\hline Upholstering & $\begin{array}{l}\text { Waiting, Unbalanced operations, Production without } \\
\text { flow, Non-standard operations, Unorganized workplace }\end{array}$ \\
\hline
\end{tabular}

\subsubsection{Frame Workshop Layout Improvement Applications}

When the workflows of the top-selling GST, FLX, STL product families are examined, the frame section is the first stage of the production process. As determined in the current situation value stream map analysis, unnecessary transportation, unnecessary movements, waiting, excess stock, and excess production wastes were determined in this section considering the wastes above, a project to improve the frame workshop layout has emerged. The following steps have been applied to realize this project:

1) Examining prescriptions and routes,

2) Determining the parts and machine groups by considering all the alternative machines that the parts in the production can be processed, 
3) Creation of the part-machine matrix,

4) Using clustering method according to operation similarities in part-machine matrices,

5) If there is an exceptional situation in the operations, separate clustering (orienting to one-piece flow with clustering),

6) Holistic analysis of the clustering method,

7) Designing different options for the frame workshop layout to minimize the delays in the value stream according to the clusters made,
8) Selecting the most beneficial option from the different machine layout options evaluated according to the rules below:

I Material flows are in such a way as to prevent returns,

II Develop machine competencies,

III Choose the one with the maximum total profit according to the selected product/products.

9) If the distance and time obtained from the comparison of the existing and new settlement is useful, apply that option. The clustering result is shown in Tabs. 2, 3 and 4.

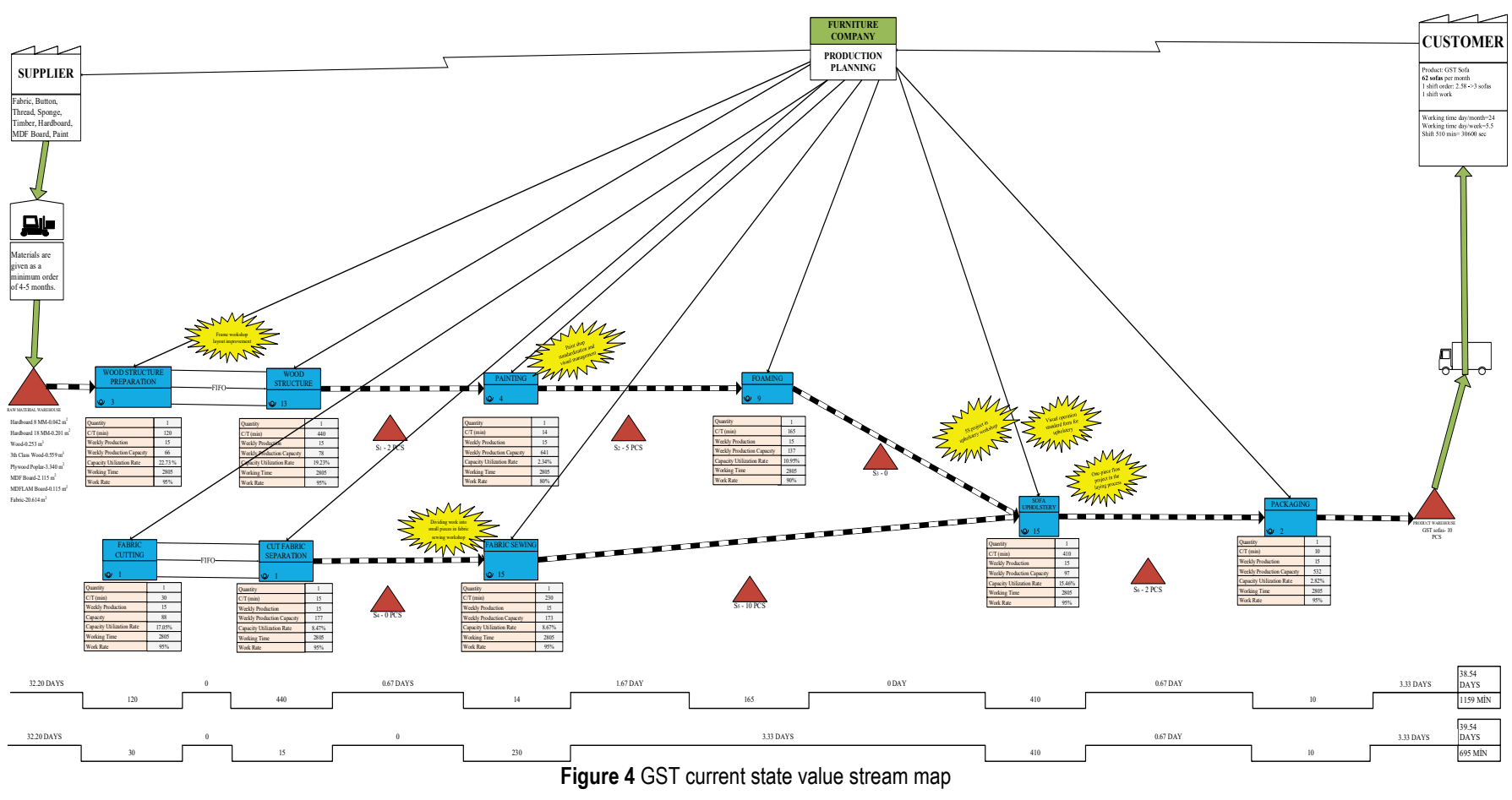

In the next step, the number of parts made on the machines for each product was determined. The total number of parts processed in the 10 machines was determined to be 200 in the GST sofa, 166 in the FLX sofa and 126 in the STL sofa (Tab. 5).

According to Table 5, rules have been created for the machine layouts of the products. These rules are:

I According to the clustering method, in the new layout, the M2 machine and the M1 machine should be close to each other.

II The M5 - M6 - M7 machines should be close to each other.

III The M8 - M9 machines should be close to each other.

As the next step, the spaghetti diagram method was used for the benefit analysis of the current situation and the designed future situation layout plan. Spaghetti diagrams of the products were drawn for current state, and distance was calculated based on the movements of the 3 main raw materials (Hardboard, Wood, MDF hardboard). Then the layout established based on constraints and distance was calculated again for comparing current state and future layout. Detail of spaghetti diagrams shown on Fig 5 (see Appendix).

To calculate the effect of the study on the company, the improvement amounts were multiplied by the annual sales amounts and added together. As a result, $868.67 \mathrm{~km}$ less walking of the employees and at the same time 14477.79 minutes, that is, 241.30 hours (approximately 30 working days), were gained to the company (Tabs. 6 - see Appendix and Tab. 7).

\subsubsection{Paint Workshop Standardization and Visual Management}

When we list the problems in the paint workshop in the current situation value stream map, the color tone difference in the products has been determined as the biggest and most common problem. To eliminate the problem, root cause analysis was performed and as a solution, standardization and visual management from lean production techniques were applied. For standardization, a paint mixture recipe was created for each color and placed on the worktables in the paint shop with a painted sample (Tab. 8). 
Dilsad Guzel et al.: Increasing Productivity of Furniture Factory with Lean Manufacturing Techniques (Case Study)

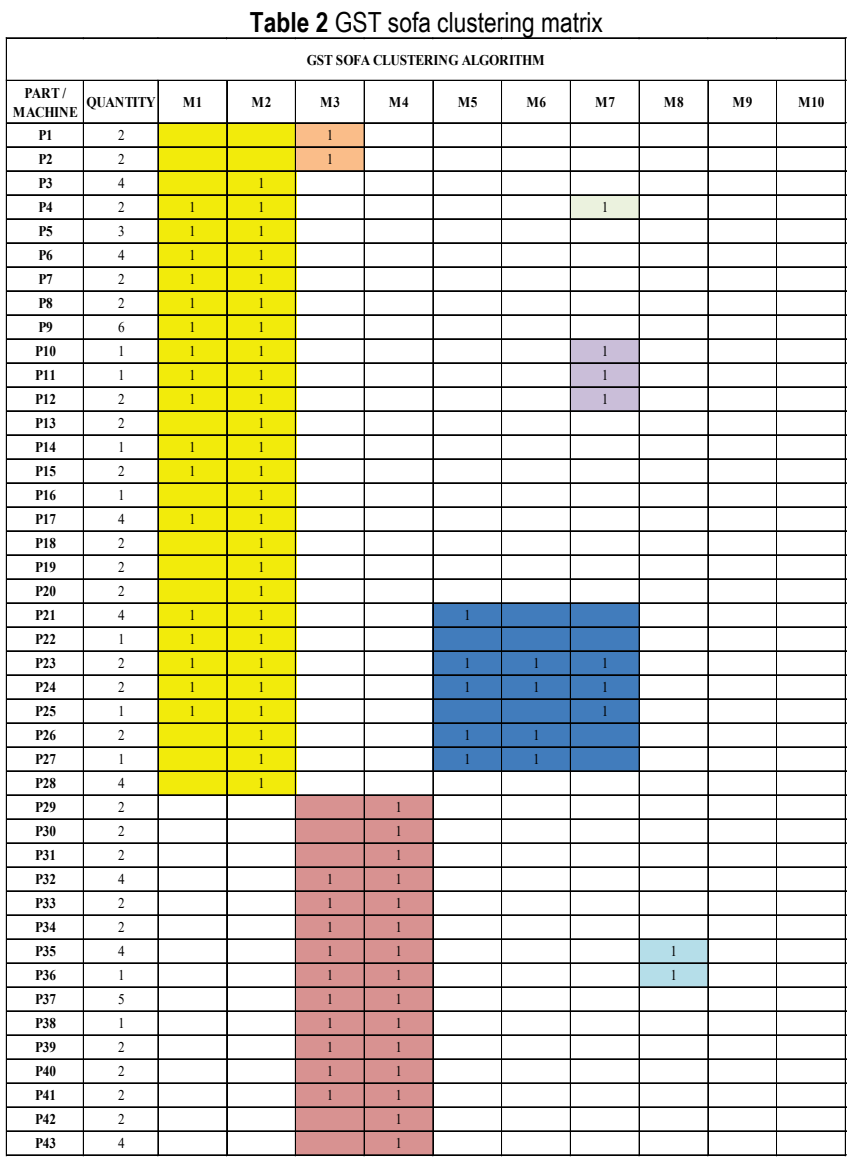

Table $3 \mathrm{FLX}$ sofa clustering matrix

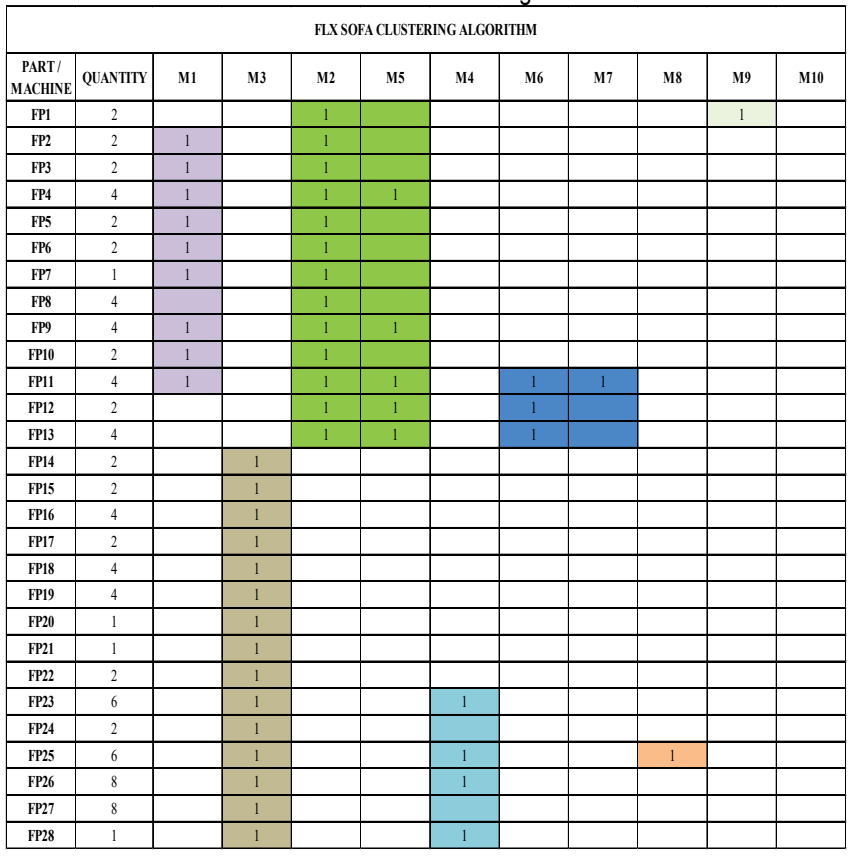

Table 4 STL sofa clustering matrix

\begin{tabular}{|c|c|c|c|c|c|c|c|c|c|c|c|}
\hline \multicolumn{12}{|c|}{ STL SOFA CLUSTERING ALGORITHM } \\
\hline $\begin{array}{l}\text { PART/ } \\
\text { MACHINE }\end{array}$ & QUANTITY & M1 & M2 & M5 & м6 & M7 & M10 & м3 & м8 & м9 & M4 \\
\hline SP1 & 1 & & & & & & & 1 & & & \\
\hline SP2 & 1 & & & & & & & 1 & & & \\
\hline SP3 & 1 & & & & & & & 1 & & & \\
\hline SP4 & 1 & & & & & & & 1 & & & \\
\hline SP5 & 2 & & & & & & & 1 & & & \\
\hline SP6 & 2 & 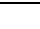 & & & & & & 1 & 1 & 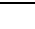 & \\
\hline $\mathrm{sp} 7$ & 1 & & & & & & & 1 & & & \\
\hline SP8 & 4 & & & 1 & & & & 1 & & & \\
\hline SP9 & 2 & & & & & & & 1 & & 1 & \\
\hline SP10 & 2 & & & & & & & 1 & & & \\
\hline SP11 & 2 & & & & & & & 1 & & & \\
\hline SP12 & 2 & & & & & & & 1 & & & \\
\hline SP13 & 1 & & & 1 & & & & 1 & & & \\
\hline SP14 & 2 & 1 & 1 & & & & & & & & \\
\hline SP15 & 1 & 1 & 1 & & & & & & & & \\
\hline SP16 & 2 & & 1 & & & & & & & & \\
\hline SP17 & 8 & 1 & 1 & & & & & & & & \\
\hline SP18 & 2 & 1 & 1 & & & & & & & & \\
\hline SP19 & 4 & 1 & 1 & & & & & & & & \\
\hline SP20 & 2 & 1 & 1 & 1 & 1 & 1 & 1 & & & & \\
\hline SP21 & 2 & 1 & 1 & 1 & 1 & 1 & 1 & & & & \\
\hline SP22 & 1 & 1 & 1 & & & & & & & & \\
\hline SP23 & 4 & & 1 & 1 & 1 & & & & & & \\
\hline SP24 & 1 & & 1 & 1 & 1 & & & & & & \\
\hline SP25 & 7 & 1 & 1 & & & & & & & & \\
\hline SP26 & 2 & $\frac{1}{1}$ & 1 & & & & & & & & \\
\hline SP27 & 1 & & & & & & & & & & \\
\hline
\end{tabular}

Table 5 Number of parts made on each machine based on product

\begin{tabular}{|c|c|c|c|}
\hline Machines & $\begin{array}{c}\text { Total number of } \\
\text { parts (GST) }\end{array}$ & $\begin{array}{c}\text { Total number of } \\
\text { parts (FLX) }\end{array}$ & $\begin{array}{c}\text { Total number of } \\
\text { parts (STL) }\end{array}$ \\
\hline M1 & 40 & 21 & 31 \\
\hline M2 & 60 & 33 & 38 \\
\hline M3 & 29 & 53 & 22 \\
\hline M4 & 37 & 21 & 0 \\
\hline M5 & 11 & 16 & 14 \\
\hline M6 & 7 & 10 & 9 \\
\hline M7 & 11 & 4 & 4 \\
\hline M8 & 5 & 6 & 2 \\
\hline M9 & 0 & 2 & 2 \\
\hline M10 & 0 & 0 & 4 \\
\hline
\end{tabular}

Table 7 One-year total improvement

\begin{tabular}{|c|c|c|c|c|}
\hline $\begin{array}{c}\text { Product Name/ } \\
\text { Improvement Type }\end{array}$ & \multicolumn{4}{|c|}{ Improvement By Annual Sales Amount } \\
\cline { 2 - 5 } & GST & FLX & STL & Total \\
\hline $\begin{array}{c}\text { Total Part - Steps } \\
\text { Number }\end{array}$ & 665550 & 284404 & 135880 & 1085834 \\
\hline Total Distance (m) & 532440 & 227523,2 & 108704 & 868667,2 \\
\hline Total Time (min) & 8874,00 & 3792,05 & 1811,73 & 14477,79 \\
\hline
\end{tabular}

Table 8 PLM Product Paint Recipe

\begin{tabular}{|c|c|}
\hline \multicolumn{2}{|c|}{ Table 8 PLM Product Paint Recipe } \\
\hline X Color & Quantity (grams) \\
\hline A & 8000 \\
\hline B & 1500 \\
\hline C & 500 \\
\hline D & 250 \\
\hline E & 200 \\
\hline F & 250 \\
\hline G & 20 \\
\hline
\end{tabular}

At the same time, model-color charts were prepared to ensure control by comparing the dyed products with the standard product color (Fig. 6).

As a result of the improvements, the number of malfunctions due to wrong color painting before the project decreased from 10 in April and 7 in June to 2 in July (Fig. 7). 


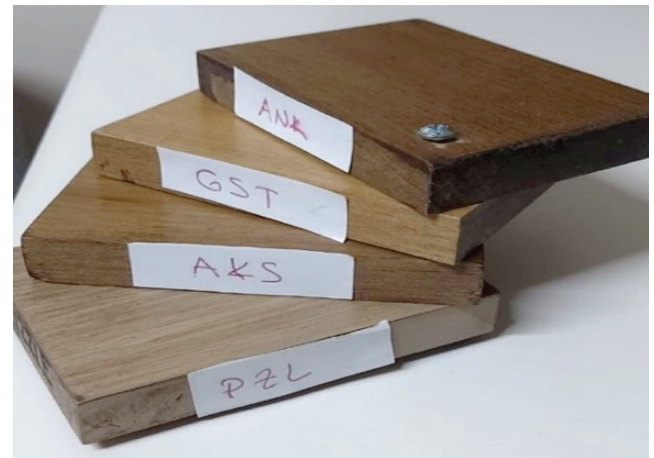

Figure 6 Model-color charts

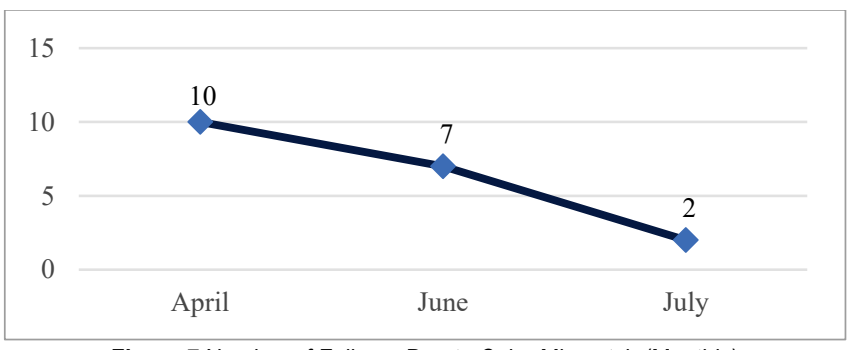

Figure 7 Number of Failures Due to Color Mismatch (Monthly)

\subsubsection{Dividing Work into Small Pieces in Fabric Sewing Workshop}

In the current situation, the set ( 2 sofas and 2 bergère) belonging to the order in the sewing workshop are all made by a single employee. When this working method is applied, problems arise due to the long duration of the sewing process, waiting in the next processes and backlogs after cutting. At the same time, in cases where the employee is off, the work done by that employee is stopped and, due to this reason, delays occur in the next workflow. In this improvement, a set consisting of 4 parts was distributed to separate personnel, and a one-piece flow was ensured. In this way, the waiting time of the upholstery section has changed from the sewing time of 1 set to the sewing time of 1 piece. In addition, when we analyzed employee-based product sewing times, it was determined that there were great differences between them. To solve this problem and increase the productivity of the total employees, each employee was given the fastest job in the work distribution. As the first result of the improvement project, while the average processing time of 3 employees (BK-RG-UY) was 620 minutes before the project, it decreased to 508 minutes after the project implementation (Fig. 8).

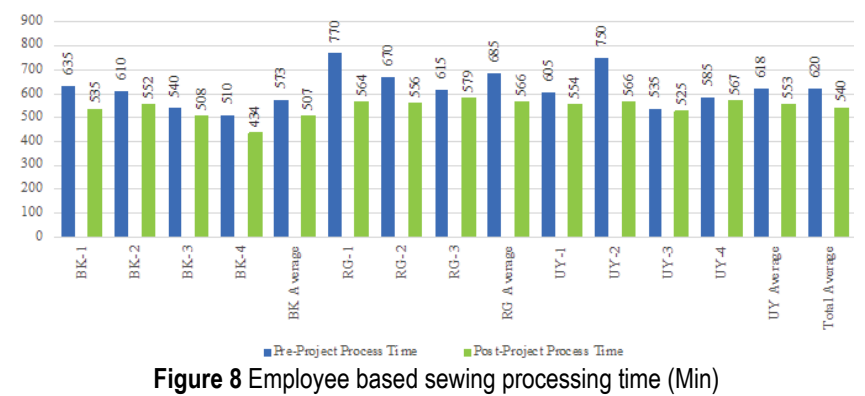

Figure 8 Employee based sewing processing time (Min)
At the same time, since we have divided the work into small parts (4 parts), the waiting time for the next process (Upholstery) from sewing has decreased from 508 minutes to 180 minutes on average (Fig. 9).

\section{Sofa Set; 508}

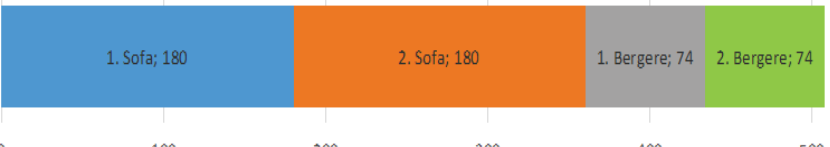

Figure 9 Work division chart in sewing process

\subsubsection{Implementation Lean Techniques in Upholstery Workshop}

As a result of the evaluation of the current situation value stream map, it was determined that there were delays in delivery. When we went to the cause of this problem, it was determined that the reason for the delays was the long duration of the upholstery process. For the continuation of the steady-state analysis, historical data were collected and analyzed. The processing time consists of four parts: 1 . Material preparation time, 2. Search for tools, 3. Upholstery process time, 4. Waiting time for semi-finished products from previous processes. Another result obtained in the analysis of the times is that different employees complete the same job at very different times. Finally, to solve the problem $5 \mathrm{~S}$, one-piece flow and Kaizen from lean manufacturing techniques were used.

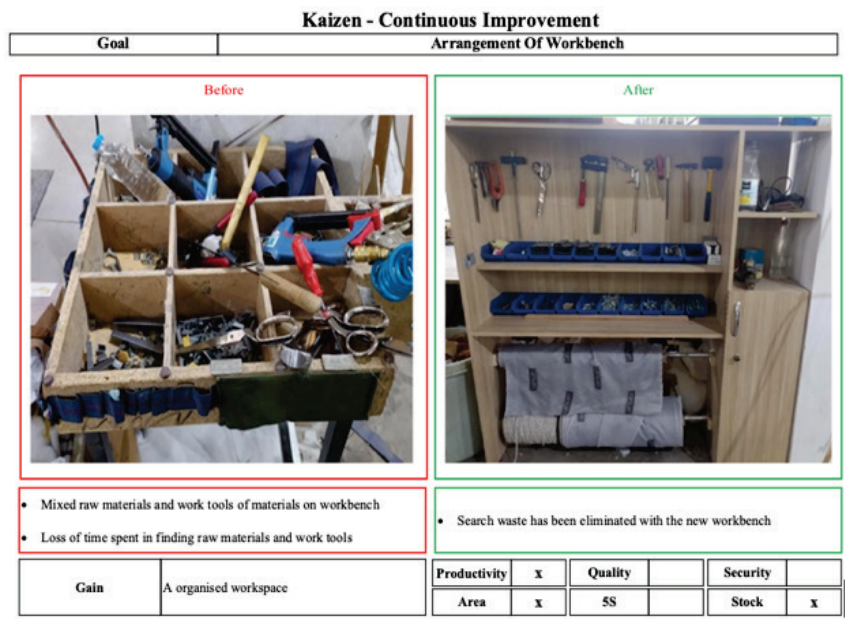

Figure $105 \mathrm{~S}$ implementation in workbench

\subsubsection{5S Project in Upholstery Workshop}

As seen in Fig. 10, raw materials and work tools were placed next to the worktable in a mixed state and in an undefined state. For this reason, it seemed that the search for materials and tools took a long time during the work. To eliminate the waste of searching for materials and tools, $5 \mathrm{~S}$ and Kaizen application was used. First, the necessary and unnecessary materials were separated, and the unused 
materials were transferred to the warehouse, then a unique workbench was designed by brainstorming with the employees for the necessary materials. In this workbench, places for all materials to be used have been reserved and arranged. After the implementation of the $5 \mathrm{~S}$ project, a $50 \%$ improvement was achieved in the time of searching for materials and vehicles.

\subsubsection{Visual Operation Standard Form for Upholstery}

When the same product is made by different personnel, it has been determined that there are differences in production times. To find the root cause of this problem, work and time-study analyzes of the product-based upholstery process were made on different employees. As a result of the work study analysis, it was determined that different employees made process in different order of operations. As the first step of this improvement, the standard work steps of the process were defined with the employees. In the next step, the operations to be done in each step are visualized and added to the form to make the operation standard form easy and understandable (Fig. 11 - see Appendix). To measure the post-implementation effects of the project, the monthly average processing times of the GST seat were compared before and after the improvement. The average of GST sofa upholstery time before the project was 488 minutes and after the project to 420 minutes, $13,94 \%$ improvement was achieved in the process time (Fig. 12).

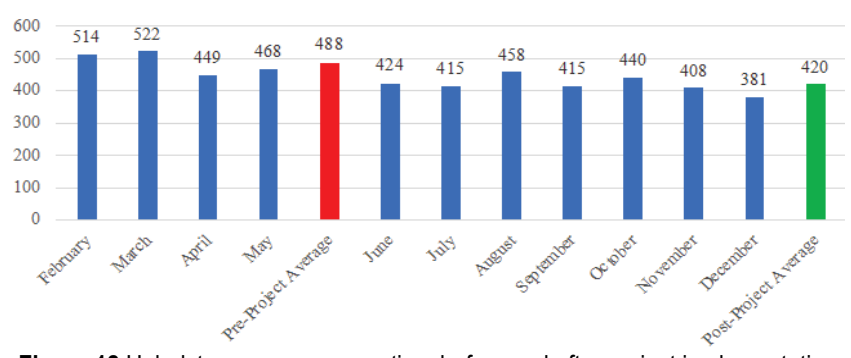

Figure 12 Upholstery process mean time before and after project implementation

\subsubsection{U-Line and Flow Manufacturing System Project in the Upholstery Process}

In the review of the current working method, it has been determined that all activities of the upholstery process are carried out by a single employee. Therefore, unbalanced work occurs in the packaging process, and the delivery time is extended. At the same time, when we look at the operation steps of the upholstery process in the work study, it has been determined that the process consists of four main parts. Since the back upholstery process was a bottleneck, eliminated unnecessary work with the Kaizen method, and the processing time was 130 minutes. Process steps and related time shown in Tab. 9.

After examining the time and operation data in Tab. 9, it was determined that the process took a short time to be done in small pieces, and, therefore, it was decided to break up the process and establish the assembly line. One of the most important issues that we should pay attention to in the design of the assembly line is that the processing times are balanced. For this reason, 2 people have been allocated for the back upholstery operation, and the operations of cushion, assembly and throw pillows have been combined. As a result of this work distribution, the longest processing time was determined as 65 minutes. As the next step, the operations are sequenced to ensure one-piece flow and forward movement of materials (Fig. 13).

Table 9 GST sofa upholstery operations and work times

\begin{tabular}{|c|l|c|}
\hline Process No & \multicolumn{1}{|c|}{ Process description } & Process time(min) \\
\hline GST-OP1 & Sofa base upholstery & 69 \\
\hline GST-OP2 & Sofa case upholstery & 59 \\
\hline GST-OP3 & Sofa back upholstery & 130 \\
\hline GST-OP4 & Sofa cushion upholstery & 23 \\
\hline GST-OP5 & Sofa assembly & 24 \\
\hline GST-OP6 & Sofa throw pillow upholstery & 9 \\
\hline \multicolumn{2}{|c|}{ Total } \\
\hline
\end{tabular}

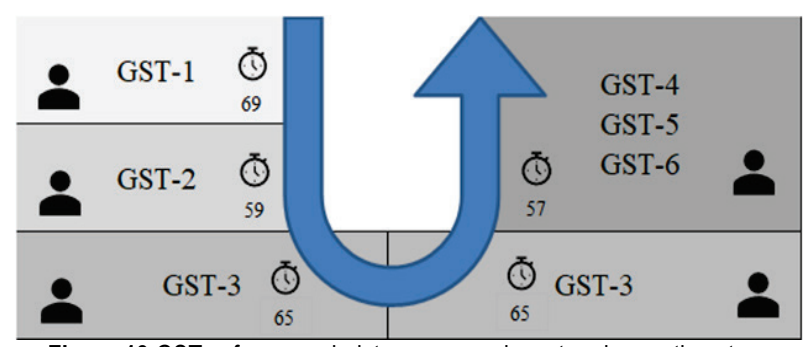

Figure 13 GST sofa new upholstery process layout and operation steps

When we apply the new working method, 5 workers produce a sofa every 65 minutes, so the total time spent on upholstery will be 330 minutes, and when we compare it with the old method, the following benefits are provided:

1) Reduced operation time by 90 minutes,

2) Quick adaptation of new workers to jobs as the process is broken down into smaller pieces,

3) Elimination of waiting and stockpile problems in downstream processes,

4) Reducing the number of semi-finished products and increasing the number of finished products in daily production,

\section{CONCLUSION}

The question of lean production practices in SMEs will lead to an increase in productivity was answered by implementing lean production techniques in the sofa manufacturing company. The current situation analysis was carried out by establishing a value stream mapping system and past data monitoring system in the sofa production factory. Lean manufacturing techniques were applied in bottleneck operations (Frame, Paint, Sewing and Upholstery) on the most produced and sold product. Reduction in time and erroneous transactions are prevented. In the next step, the work was divided into small lots to achieve the main goal of lean production, and a one-piece flow was achieved. As a result of the one-piece flow application, an improvement of $65 \%$ was achieved in waiting times. When we look at the general results, lean production practices were implemented, and annual labor times were improved by $29 \%$. As for the 
limitations of the research, data collection difficulties are obtaining correct data from employees and employees' opposition to change. In this study, all techniques of lean manufacturing were not used. In future studies, the effect of lean production on productivity can be investigated by realizing other applications in different sectors.

\section{REFERENCES}

[1] Womack, J., Jones, D., \& Roos, D. (1990). The Machine that Changed the World. New York, United States. Simon \& Schuster.

[2] George, M. L. (2002). Lean Six Sigma. New York: McgrawHill.

[3] Choomlucksanaa, J. et al. (2015). Improving the productivity of sheet metal stamping subassembly area using the application of lean manufacturing principles. Procedia Manufacturing, 2, 102-107. https://doi.org/10.1016/j.promfg.2015.07.090

[4] Tütek, H. \& Öncü, S. (1992). Jit (Just In Time) Felsefesi'nin İşletme Fonksiyonlari Ve Verimlilik Üzerinde Etkileri [Effects of Jit (Just In Time) Philosophy on Business Functions and Efficiency]. Erciyes Üniversitesi İktisadi Ve İdari Bilimler Fakültesi Dergisi, (10), 112-129.

[5] Womack, J. P. \& Jones, D. T. (2003). Lean Thinking. New York: A Division Of Simon \& Schuster, Inc.

[6] Gökçe, İ. (2006). Mevcut Üretim Sürecinin Yalin Üretim Yaklaşimiyla Yeniden Yapilandirilmasi Ve Bir Uygulama [Restructuring the Existing Manufacturing Process with the Lean Manufacturing Approach and an Application]. Yüksek Lisans Tezi. İzmir: Dokuz Eylül Üniversitesi, Sosyal Bilimler Enstitüsü.

[7] Okur, S. A. (1997). 2000'li Yillarda Sanayi İçin Yapilanma Modeli: Yalin Üretim [Structuring Model for Industry in the 2000s: Lean Production]. İstanbul: Söz Yayinlari.

[8] S. Birgün, K. G. (2006). Yalin Üretime Geçiş Sürecinde Değer Akişi Haritalama Tekniğinin Kullanilmasi: İmalat Sektöründe Bir Uygulama [Using Value Flow Mapping Technique in the Transition to Lean Manufacturing: An Application in Manufacturing Sector]. İstanbul Ticaret Üniversitesi Fen Bilimleri Dergisi, 47-59.

[9] Rother, M. \& Harris, R. (2001). Creating Continuous Flow Book. Brookline: Lean Enterprise Institute, Inc.

[10] Wilson, L. (2010). How to Implement Lean Manufacturing. New York: McGraw Hill.

[11] Bicheno, J. H. M. (2008). The Lean Toolbox. Buckingham: Picsie Books.

[12] Martin Tanco, J. S. (2013). Applying Lean Techniques to Nougat Fabrication: A Seasonal Case Study. The International Journal of Advanced Manufacturing Technology, 1639-1654. https://doi.org/10.1007/s00170-013-4960-7

[13] Wilson, L. (2009). How to Implement Lean Manufacturing. New York: McGraw Hill.

[14] Imai, M. (2013). Gemba Kaizen: A Practical Approach to a Continuous Improvement Strategy, Second Edition. Bucuresti: Kaizen Publishing House.

[15] Patel, V. C. \& Thakkar, H. (2014). Review on Implementation of $5 \mathrm{~S}$ in Various Organization. International Journal of Engineering Research and Applications, 4(3), 774-779.

[16] Sorooshian, S., Salami, M., Bavani, S., \& Aminattaheri, H. (2012). Case Report: Experience of 5S Implementation. Anansi Publisher American-Eurasian Network for Scientific Information, http://www.aensiweb.com/old/jasr/jasr/2012/3855-3859.pdf
[17] Kaushik, K. et al. (2012). Step for Implementation of 5S. International Journal of Management, IT and Engineering, 2(6), 402-416.

[18] Rojasara, P. M. \& Qureshi, M. (2013). Performance Improvement through 5S in Small Scale Industry: A case study. International Journal of Modern Engineering Research (IJMER), 3(3), 1654-1660.

[19] Khedkar, S. B. et al. (2012). Study of Implementing 5S Techniques in Plastic Moulding. International Journal of Modern Engineering Research, 2(5), 3653-3656.

[20] Buesa, R. (2009). Adapting Lean to Histology Laboratories. Annals of Diagnostic Pathology, 322-333. https://doi.org/10.1016/j.anndiagpath.2009.06.005

[21] Sarkar, D. (2006). 5S For Service Organizations and Offices a Lean Look at Improvements. Wisconsin: ASQ Quality Press Milwaukee.

[22] Ören, K. (2002). Toplam Kalite Yönetiminde İnsan Gücü Faktörü [People Power Factor in Total Quality Management]. Ankara: Nobel Yayin Dağitim

[23] Elvinaz, T. (2002). Toplam Kalite Yönetiminde Çalişanlarin İş Tatmini İle Bireysel Başarisi Arasindaki İlişkinin İncelenmesi Üzerine Bir Araştirma[A Research On The Relationship Between Employee Job Satisfaction And Individual Success In Total Quality Management]. Yüksek Lisans Tezi. Gebze: Gebze Yüksek Teknoloji Enstitüsü.

[24] Berger, A. (1997). Continuous Improvement and Kaizen: Standardization and Organizational Designs. Integrated Manufacturing Systems, 89, 110-117. https://doi.org/10.1108/09576069710165792

[25] Jamie, W. F. (1998). Implementing Lean Manufacturing through Factory Design. Massachusetts Institute of Technology.

[26] Das, K., Lashkari, R. S., \& Sengupta, S. (2007). Reliability consideration in the design and analysis of cellular manufacturing systems. International Journal of Production Economics, 105(1), 243-262. https://doi.org/10.1016/j.jpe.2006.04.015

[27] Monden, Y. (1983). Toyota Production System. Norcross, Ga: Industrial Engineering and Management Press.

[28] Rother, M. \& Shook, J. (1998). Learning to See: Value Stream Mapping to Add. Lean Enterprise Institute, Inc.

[29] Guerriero, F. \& Miltenburg, J. (2003). The stochastic U-Line balancing problem. Naval Research Logistics (NRL), 50, 3157. https://doi.org/10.1002/nav.10043

[30] Miltenburg, J. (2001). U-Shaped Production Lines a Review of Theory and Practice. Int. J. Production Economics, 70, 201204. https://doi.org/10.1016/S0925-5273(00)00064-5

\section{Authors' contacts:}

\section{Dilsad Guzel}

Department of Business,

Faculty of Economics and Administrative Sciences,

Ataturk University, 25240 Erzurum, Turkey

E-mail: dguzel@atauni.edu.tr

\section{Alireza Shahbazpour Asiabi}

(Corresponding author)

Department of Business,

Faculty of Economics and Administrative Sciences,

Ataturk University, 25240 Erzurum, Turkey

E-mail: alireza.shahbazpourasiabi14@ogr.atauni.edu.tr 


\section{Appendix}
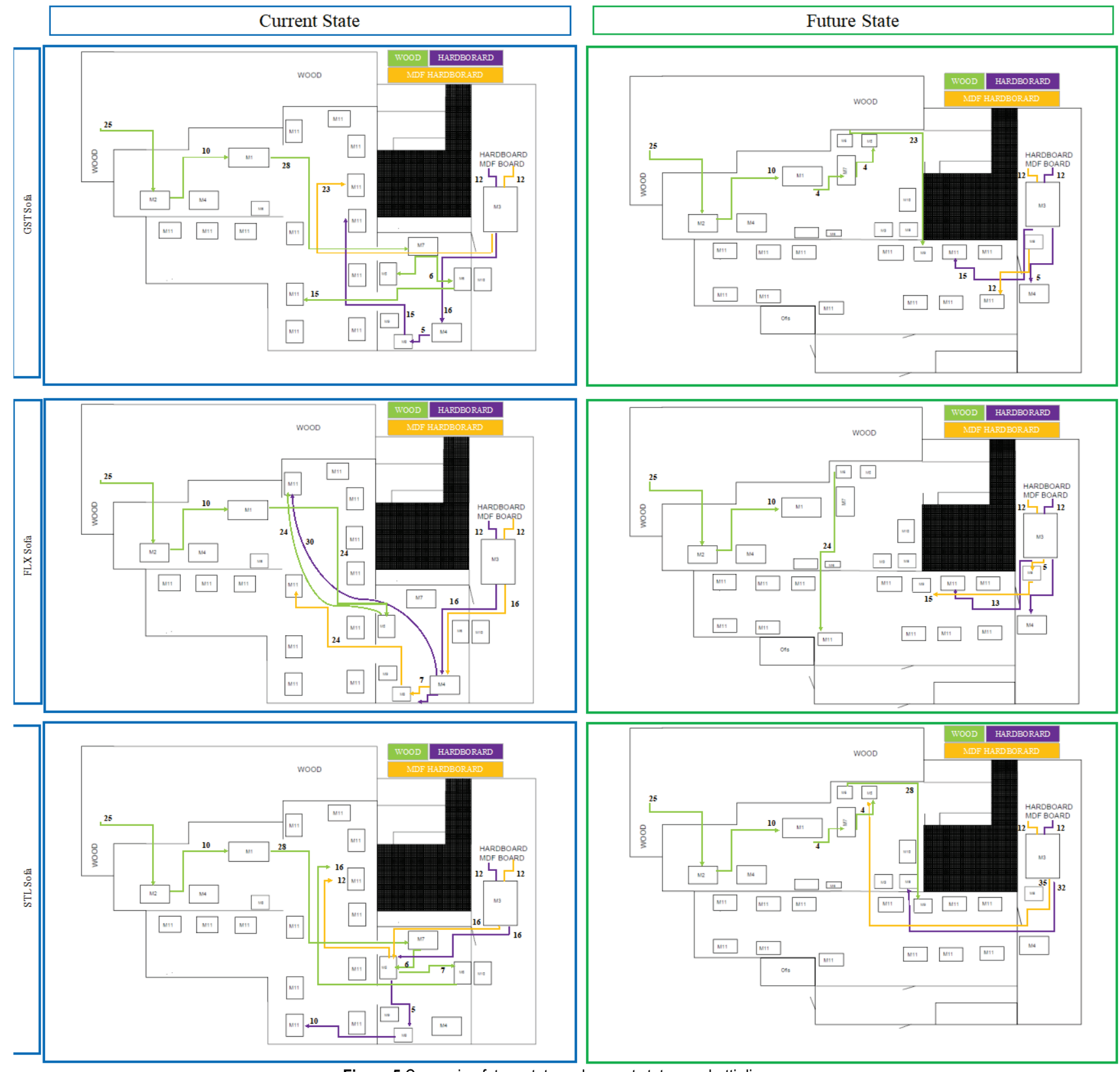

Figure 5 Comparing future state and current state spaghetti diagram

\begin{tabular}{|c|c|c|c|c|c|c|c|c|c|c|c|c|c|c|c|c|c|c|}
\hline & \multicolumn{3}{|c|}{ Old Settlement Plan } & \multicolumn{3}{|c|}{ New Settlement Plan } & \multicolumn{3}{|c|}{ Old Settlement Plan } & \multicolumn{3}{|c|}{ New Settlement Plan } & \multicolumn{3}{|c|}{ Old Settlement Plan } & \multicolumn{3}{|c|}{ New Settlement Plan } \\
\hline & $\begin{array}{c}\text { Total } \\
\text { Part - } \\
\text { Steps } \\
\text { Number }\end{array}$ & $\begin{array}{c}\text { Total } \\
\text { Distance } \\
\text { (m) }\end{array}$ & $\begin{array}{l}\text { Total } \\
\text { Time } \\
\text { (min) }\end{array}$ & $\begin{array}{c}\text { Total } \\
\text { Part - } \\
\text { Steps } \\
\text { Number }\end{array}$ & $\begin{array}{c}\text { Total } \\
\text { Distance } \\
\text { (m) }\end{array}$ & $\begin{array}{l}\text { Total } \\
\text { Time } \\
(\mathrm{min})\end{array}$ & $\begin{array}{c}\text { Total } \\
\text { Part - } \\
\text { Steps } \\
\text { Number }\end{array}$ & $\begin{array}{c}\text { Total } \\
\text { Distance } \\
(\mathrm{m})\end{array}$ & $\begin{array}{l}\text { Total } \\
\text { Time } \\
(\mathrm{min})\end{array}$ & $\begin{array}{c}\text { Total } \\
\text { Part - } \\
\text { Steps } \\
\text { Number }\end{array}$ & $\begin{array}{c}\text { Total } \\
\text { Distance } \\
(\mathrm{m})\end{array}$ & $\begin{array}{l}\text { Total } \\
\text { Time } \\
(\mathrm{min})\end{array}$ & $\begin{array}{c}\text { Total } \\
\text { Part - } \\
\text { Steps } \\
\text { Number }\end{array}$ & $\begin{array}{c}\text { Total } \\
\text { Distance } \\
(\mathrm{m})\end{array}$ & $\begin{array}{l}\text { Total } \\
\text { Time } \\
(\mathrm{min})\end{array}$ & $\begin{array}{c}\text { Total } \\
\text { Part - } \\
\text { Steps } \\
\text { Number }\end{array}$ & $\begin{array}{l}\text { Total } \\
\text { Distance } \\
\text { (m) }\end{array}$ & $\begin{array}{l}\text { Total } \\
\text { Time } \\
(\mathrm{min})\end{array}$ \\
\hline \multicolumn{7}{|c|}{ GST Sofa } & \multicolumn{6}{|c|}{ FLX Sofa } & \multicolumn{6}{|c|}{ STL Sofa } \\
\hline Wood & 2370 & 1896 & 31,6 & 1554 & 1243,2 & 20,7 & 771 & 616,8 & 10,3 & 688 & 550,4 & 9,2 & 1284 & 1027,2 & 17,1 & 930 & 744 & 12,4 \\
\hline Hardboard & 322 & 257,6 & 4,3 & 328 & 262,4 & 4,4 & 390 & 312 & 5,2 & 232 & 185,6 & 3,1 & 212 & 169,6 & 2,8 & 196 & 156,8 & 2,6 \\
\hline MDF Board & 104 & 83,2 & 1,4 & 64 & 51,2 & 0,9 & 386 & 308,8 & 5,1 & 239 & 191,2 & 3,2 & 104 & 83,2 & 1,4 & 79 & 63,2 & 1,1 \\
\hline Total & 2796 & 2236,8 & 37,28 & 1946 & 1556,8 & 25,95 & 1547 & 1237,6 & 20,63 & 1159 & 927,2 & 15,45 & 1600 & 1280,0 & 21,33 & 1205 & 964,0 & 16,07 \\
\hline \multirow[t]{3}{*}{ Gain } & \multicolumn{3}{|c|}{ Total Part - Steps Number } & \multicolumn{3}{|c|}{850} & \multicolumn{3}{|c|}{ Total Part - Steps Number } & \multicolumn{3}{|c|}{388} & \multicolumn{3}{|c|}{ Total Part - Steps Number } & \multicolumn{3}{|c|}{395} \\
\hline & \multicolumn{3}{|c|}{ Total Distance (m) } & \multicolumn{3}{|c|}{680,00} & \multicolumn{3}{|c|}{ Total Distance (m) } & \multicolumn{3}{|c|}{310,40} & \multicolumn{3}{|c|}{ Total Distance (m) } & \multicolumn{3}{|c|}{316,00} \\
\hline & \multicolumn{3}{|c|}{ Total Time (min) } & \multicolumn{3}{|c|}{11,33} & \multicolumn{3}{|c|}{ Total Time (min) } & \multicolumn{3}{|c|}{5,17} & \multicolumn{3}{|c|}{ Total Time (min) } & \multicolumn{3}{|c|}{5,27} \\
\hline
\end{tabular}




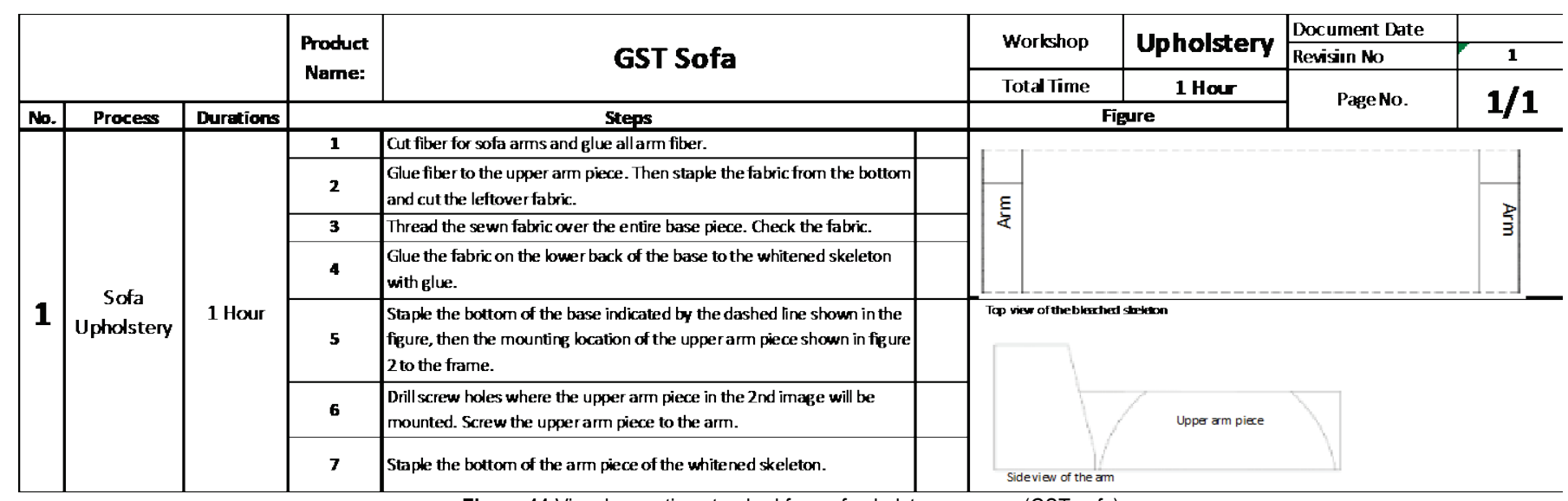

Figure 11 Visual operation standard form of upholstery process (GST sofa) 